\title{
ANALISIS KOMPARASI USAHATANI PADI SAWAH PENGGUNA BENIH BERSERTIFIKAT DAN BENIH NON SERTIFIKAT DI KELURAHAN KEMUMU KECAMATAN ARMA JAYA KABUPATEN BENGKULU UTARA
}

\section{Comparation Analysis Of Paddy Farming Between Certified Seeds And Non Certified Seeds User In Kemumu Village Arma Jaya Subdistrict Bengkulu Utara Regency}

Reza Raditya, Putri Suci Asriani, dan Sriyoto Jurusan Sosial Ekonomi Pertanian Fakultas Pertanian Universitas Bengkulu

\begin{abstract}
This research purposse are to calculate and compare the productivity of land, income, and efficiency between paddy farming using certified seed and paddy farming which uses non-certified seed. The research was conductedin the village of Kemumu with a total sample of 15 farmers certified seed specified users using census method and 22 non-certified seed user farmers were determined using purposive sampling method. Methods of data analysis using quantitative analysis and qualitative (descriptive). The analysis showed that the average productivity of the land $(5,112 \mathrm{Ton} / \mathrm{Ha})$, average income (Rp 16.501.384,77/Ha), and the average efficiency $(3,91)$ forpaddy farming using certified seed. While the average productivity of the land $(3,918 \mathrm{Ton} / \mathrm{Ha})$, the average income ( $R p$ 10.951.035,29/Ha), and the average efficiency (3.24) for paddy farming which uses non-certified seed. Based onthe results ofthe analysis, itcan be concluded that certified seed is better than non-certified seed both in terms of land productivity, income, and efficiency.
\end{abstract}

Key words: certified and non certified seeds, productivity of land, income, efficiency

\section{PENDAHULUAN}

Salah satu faktor penting yang mempengaruhi peningkatan produksi padi adalah penggunaan benih yang unggul dan berkualitas, sebab penggunaan benih yang unggul dan berkualitas dapat meningkatkan produktivitas tanaman padi. Selain itu, penggunaan benih unggul dapat meningkatkan frekuensi panen dari satu kali menjadi dua kali atau bahkan tiga kali dalam setahun. Peningkatan produktivitas tanaman padi yang diiringi dengan peningkatan luas panen akan meningkatkan produksi padi secara nyata (Badan Pusat Statistik, 2009).

Wilayah Kelurahan Kemumu, sebagian besar masyarakatnya mengusahakan tanaman padi sawah. Petani di Kelurahan Kemumu 
mengusahakan tanaman padi dengan menggunakan benih padi bersertifikat dan benih padi non sertifikat. Benih padi bersertifikat merupakan penanaman benih padi berlabel yang prosesnya diawasi oleh pengawas benih dari BPSB (Balai Pengawasan dan Sertifikasi Benih), dimana prosesnya diawasi mulai dari proses penanaman sampai panen. Petani padi di Kelurahan Kemumu menggunakan benih bersertifikat yang berlabel PT PERTANI UPB Sukasari. Beberapa keunggulan dari benih padi bersertifikat adalah pertumbuhannya seragam, lebih tahan terhadap hama dan penyakit, respon terhadap pemupukan dan hasil panennya atau produksinya tinggi.

Benih padi non sertifikat adalah benih unggul tidak berlabel yang berasal dari hasil panen petani sendiri atau diperoleh dari petani lainnya atau dari hasil penangkaran yang dilakukan oleh petani itu sendiri, adapun kelemahan dari benih padi non sertifikat ini diantaranya adalah tidak tahan terhadap serangan hama dan penyakit, tidak respon terhadap pemupukan dan pertumbuhannya tidak seragam serta bila ditanam secara terus menerus dalam jangka waktu yang lama maka akan dapat menurunkan kualitas benih padi itu sendiri, maka tanaman akan mengalami kemunduran sehingga hasil dan mutunya semakin menurun. Bila dilihat dari keunggulaannya sudah jelas bahwa benih padi yang bersertifikat lebih baik, tetapi pada kenyataannya masih banyak, bahkan mayoritas petani di Kelurahan Kemumu yang menanam dengan menggunakan benih padi non sertifikat.

Adanya kenyataan bahwa terdapat petani di Kelurahan Kemumu yang mengusahakan usahatani padi sawah dengan menggunakan benih bersertifikat dan benih non sertifikat, penulis merasa penting untuk melakukan penelitian terkait analisis komparasi usahatani padi sawah pengguna benih bersertifikat dan benih non sertifikat di Kelurahan Kemumu Kecamatan Arma Jaya Kabupaten Bengkulu Utara, dengan tujuan untuk: 1) Menghitung dan menganalisis produktivitas lahan usahatani padi sawah yang menggunakan benih bersertifikat dengan produktivitas lahan usahatani padi sawah yang menggunakan benih non sertifikat, 2) Menguji beda tingkat produktivitas lahan usahatani padi sawah dengan benih bersertifikat dan benih non sertifikat, 3) Menghitung dan menganalisis pendapatan usahatani padi sawah yang menggunakan benih bersertifikat dengan pendapatan usahatani padi sawah yang menggunakan benih non sertifikat, 4) Menguji beda tingkat pendapatan usahatani padi sawah dengan benih bersertifikat dan benih non sertifikat dan 5) Menghitung dan menganalisis efisiensi usahatani padi sawah yang menggunakan benih bersertifikat dengan efisiensi usahatani padi sawah yang menggunakan benih non sertifikat. 


\section{METODE PENELITIAN}

Penelitian ini dilakukan di Kelurahan Kemumu, Kecamatan Arma Jaya, Kabupaten Bengkulu Utara, Provinsi Bengkulu, pada bulan April-Mei 2015. Pemilihan lokasi ini dilakukan dengan cara purposive (sengaja). Responden untuk petani yang menggunakan benih bersertifikat dilakukan dengan metode sensus. Berdasarkam sensus yang telah dilakukan maka jumlah responden terdiri dari 15 orang petani padi sawah yang menggunakan benih bersertifikat. Responden untuk petani yang menggunakan benih non sertifikat dilakukan dengan metode purposive sampling (pengambilan sampel sengaja), yaitu jumlah pengambilan sampel berdasarkan kriteria tertentu dengan pertimbangan tertentu, dimana peneliti menentukan dengan sengaja sampel yang akan diteliti.

Data yang dikumpulkan dalam penelitian ini terdiri dari data primer dan data sekunder. Pada penelitian inidataprimer diperoleh melalui pengisian kuesioner oleh peneliti berdasarkan hasil wawancara dengan responden (petani sampel di desa penelitian), diskusi dengan kepala narasumber terkait seperti Aparat Desa, Aparat Kecamatan, dan beberapa narasumber-narasumber lainnya yang dianggap memiliki informasi yang relevan dengan data yang dibutuhkan. Data sekunder yang digunakan dalam penelitian ini yaitu data yang diperoleh dari studi pustaka atau literatur, internet, instansi atau dinas terkait yang terdiri dari data demografi, monografi, luas lahan, wilayah binaan kelembagaan dan data lain yang berkaitan dengan penelitian.

\section{Analisis Produktivitas Lahan}

Untuk mengetahui produktivitas lahan sawah menggunakan rumus sebagai berikut (Mubyarto, 1991):

$$
\text { Produktifitas Lahan }=\frac{\text { Hasil produsi per MT(ton } / \mathrm{MT})}{\text { Luas Lahan }(\mathrm{Ha})}
$$

\section{Analisis Pendapatan Usahatani}

Tingkat pendapatan usahatani dapat dihitung dengan menggunakan rumus sebagai berikut (Soekartawi, 1995):

$$
\begin{aligned}
& \Pi=\mathrm{TR}-\mathrm{TC} \\
& \mathrm{TR}=\mathrm{Y} . \mathrm{P}_{\mathrm{y}} \text { dan TC }=\mathrm{FC}+\mathrm{VC}
\end{aligned}
$$

dimana P adalah pendapatan usahatani petani padi sawah (Rp/UT), TR adalah total penerimaan petani padi sawah (Rp/UT), TC adalah total biaya yang dikeluarkan petani dalam berusahatani padi sawah (Rp/UT), dan FC adalah biaya tetap dalam berusahatani padi sawah (Rp/UT) 


\section{Uji Beda Produktivitas Lahan}

Untuk menguji hipotesis yang dirumuskan, maka digunakan uji $t$ (t-test) yang besarnya nilai thitung dapat diketahui dengan rumus:

$$
t=\frac{\overline{X_{1}}-\overline{X_{2}}}{\sqrt{\frac{\left(n_{1}-1\right) s_{1}^{2}+\left(n_{2}-1\right) s_{2}^{2}}{n_{1}+n_{2}-2}\left(\frac{1}{n_{1}}+\frac{1}{n_{2}}\right)}} \quad \text { dan } s=\sqrt{\frac{\left(x_{i}-\bar{x}\right)^{2}}{(n-1)}}
$$

(Nazir, 1983)

Keterangan $\bar{X}_{1}$ adalah rata-rata produktivitas lahan pada usahatani padi sawah yang menggunakan benih bersertifikat, $\bar{X}_{2}$ adalah rata-rata produktivitas lahan pada usahatani padi sawah yang menggunakan benih non sertifikat, $\mathrm{n}_{1}$ adalah Jumlah petani sampel usahatani padi sawah yang menggunakan benih bersertifikat, $\mathrm{n}_{2}$ adalah jumlah petani sampel usahatani padi sawah yang menggunakan benih non sertifikat, $\mathrm{s}_{1}$ adalah standar deviasi produktivitas lahan usahatani padi sawah yang menggunakan benih bersertifikat, dan $\mathrm{s}_{2}$ adalah standar deviasi produktivitas lahan usahatani padi sawah yang menggunakan benih non sertifikat

\section{Analisis Efisiensi Usahatani}

Untuk menilai efisiensi usahatani padi sawah menggunakan Revenue Cost Ratio, dirumuskan sebagai berikut:

$$
R / C^{\text {ratio }_{\mathrm{i}}}=\frac{\mathrm{TR}_{\mathrm{i}}}{\mathrm{TC}_{\mathrm{i}}} \quad \text { (Soekartawi, 2002) }
$$

dimana TR adalah Besarnya penerimaan usahatani padi sawah (Rp/UT), TC adalah Besarnya biaya mengusahakan usahatani padi sawah $(\mathrm{Rp} / \mathrm{UT}), \mathrm{i}=1$, jikaPetani padi sawah dengan benih bersertifikat, dan $\mathrm{i}=2$ adalah Petani padi sawah dengan benih non sertifikat.

\section{HASIL DAN PEMBAHASAN}

\section{Karakteristik Responden}

Dari hasil penelitian terlihat tingginya persentase petani yang berumur diatas 40 tahun, hal tersebut menunjukkan bahwa pekerjaan sebagai petani padi jarang digeluti oleh kaum muda di daerah penelitian. Hal ini terjadi karena sebagian pemuda yang ada di daerah penelitian enggan bekerja sebagai petani.

Rata-rata pendidikan petani pengguna benih bersertifikat dan benih non sertifikat adalah sekolah dasar (SD). Menurut pengakuan petani pada saat 
penelitian hal tersebut dikarenakan keterbatasan ekonomi orang tua mereka dahulu dan sebagian lagi beranggapan bahwa orang tua mereka masih mampu untuk kejenjang yang lebih tinggi lagi namun orang tua mereka terutama ayah mereka beranggapan bahwa jika nantinya akan mengurus sawah juga, anakanak mereka tidak perlu mendapat latar belakang pendidikan formal yang lebih tinggi. Cukup hanya keterampilan dasar seperti membaca dan menulis di bangku sekolah dasar saja dianggap dapat membekali mereka dalam hidup di dunia pertanian.

Rata-rata petani pengguna benih bersertifikat dan benih non sertifikat memiliki pengalaman berusahatani padi masing-masing selama 22 dan 21 tahun. Pengalaman berusahatani padi sawah yang dimiliki oleh petani pengguna benih bersertifikat dan benih non sertifikat berpengaruh terhadap keahlian petani dalam melakukan kegiatan usahatani padi sawah.

Rata-rata dari petani pengguna benih bersertifikat dan benih non sertifikat memiliki jumlah tanggungan keluarga sebanyak 4 orang (termasuk petani). Jika dihubungkan dengan biaya kebutuhan hidup, berarti biaya kebutuhan hidup yang harus dikeluarkan tidak begitu besar jumlahnya karena petani hanya perlu memenuhi kebutuhan hidup diri petani itu sendiri, satu orang istri beserta dua orang anak.

Rata-rata luas lahan sawah petani pengguna benih non sertifikat $(0,67 \mathrm{Ha})$ lebih luas daripada petani pengguna benih bersertifikat $(0,53 \mathrm{Ha})$. Lahan yang lebih luas tidak menjamin produktivitas lahan akan lebih tinggi. Hal tersebut dibuktikan dari hasil penelitian ini bahwa produktivitas lahan sawah petani pengguna benih bersertifikat malah lebih tinggi jika dibanding dengan petani pengguna benih non sertifikat.

Rata-rata petani memilki status kepemilikan lahan milik sendiri, hanya sedikit yang memiliki status lahan sakap. Hal ini berarti petani di daerah penelitian bisa mengandalkan sektor pertanian dalam memenuhi kebutuhan keluarga melalui pendapatan yang mereka terima dari usahatani yang mereka kerjakan.

\section{Analisis Produktivitas Lahan}

Perbedaan besaran produktivitas antara lahan sawah yang ditanami dengan benih bersertifikat dan benih non sertifikat merupakan salah satu penyebab yang dikeluhkan oleh petani di daerah penelitian. Produktivitas lahan sawah yang ditanami benih non sertifikat lebih kecil dari pada lahan sawah yang ditanami benih bersertifikat disebabkan oleh produksi padi yang jumlahnya kecil. Selain itu, benih non sertifikat juga lebih rentan dan tidak tahan terhadap serangan hama, dan juga seringkali tidak respon terhadap pemupukan. Masalah-masalah tersebutlah yang diakui petani di daerah penelitian yang menyebabkan rendahnya hasil produksi, sehingga juga berbubungan dengan rendahnya produktivitas lahan sawah yang ditanami benih non sertifikat. 
Tabel 1. Rata-Rata Produktivitas Lahan Petani Padi Sawah Pengguna Benih Bersertifikat dan Benih Non Sertifikat MT September-Desember 2014

\begin{tabular}{clccccc}
\hline No & Petani Pengguna & $\begin{array}{c}\text { Lahan } \\
\text { (Ha) }\end{array}$ & $\begin{array}{c}\text { Produksi } \\
\text { (Ton) }\end{array}$ & $\begin{array}{c}\text { Produktivitas } \\
\text { (Ton/Ha) }\end{array}$ & $\begin{array}{c}\text { Standard } \\
\text { deviasi }\end{array}$ & thitung $^{\text {(Tonah }}$ \\
\hline 1 & $\begin{array}{l}\text { Benih } \\
\text { Bersertifikat }\end{array}$ & 0,53 & 2,672 & 5,112 & 0,797661 & 5,06 \\
2 & $\begin{array}{l}\text { Benih Non } \\
\text { Sertifikat }\end{array}$ & 0,67 & 2,607 & 3,918 & 0,70789 & \\
\hline
\end{tabular}

Sumber: Data Primer Diolah (2015)

Hipotesis yang diajukan dalam penelitian ini adalah produktivitas lahan pada usahatani padi sawah yang menggunakan benih bersertifikat lebih tinggi daripada produktivitas lahan pada usahatani padi sawah yang menggunakan benih non sertifikat. Analisis komparasi produktivitas lahan usahatani padi sawah pengguna benih bersertifikat dan benih non sertifikat dapat dilihat pada Tabel 1.

Hasil analisis pada Tabel 1 menunjukkan bahwa produktivitas lahan pada usahatani padi sawah pengguna benih bersertifikat sebesar 5,112 Ton/Ha lebih tinggi daripada produktivitas lahan pada usahatani padi sawah pengguna benih non sertifikat sebesar 3,918 Ton/Ha. Uji perbandingan (t-test) terhadap produktivitas lahan usahatani padi sawah pengguna benih bersertifikat dan benih non sertifikat memberikan nilai t-hitung $(5,06)$ lebih besar daripada nilai ttabel $(1,69)$ sehingga hipotesis diterima yang menyatakan bahwa produktivitas lahan pada usahatani padi sawah yang menggunakan benih bersertifikat lebih tinggi daripada produktivitas lahan pada usahatani padi sawah yang menggunakan benih non sertifikat.

\section{Analisis Pendapatan Usahatani}

\section{Biaya Tetap}

Biaya tetap adalah biaya yang besar kecil pengeluarannya tidak dipengaruhi besarnya produksi yang dihasilkan. Dalam penelitian ini ada dua komponen biaya tetap yang dikelurkan maupun diperhitungkan, yakni biaya penyusutan dan biaya pajak atas laha sawah ayng dimiliki oleh petani. Besarnya biaya ini per usahatani (UT) maupun per ha disajikan pada Tabel 2. Yang perlu dicatat dalam penelitian ini bahwa jenis biaya tetap terdapat biaya sewa traktor, akan tetapi tidak dimasukkan kedalam total biaya tetap karena sudah termasuk kedalam upah tenaga kerja membajak.

Penyusutan alat pertanian masuk kedalam biaya diperhitungkan karena biaya peralatan pertanian tidak dikeluarkan lagi, namun nilai barang yang sudah ada dihitung nilai penyusutannya. Menurut petani peralatan pertanian 
meskipun tidak digunakan dan tetap disimpan nilainya cenderung berkurang seiring dengan waktu.

Tabel 2. Rata-Rata Penggunaan Biaya Tetap MT September-Desember 2014

\begin{tabular}{ccrrrr}
\hline \multirow{2}{*}{ No } & \multirow{2}{*}{ Jenis Biaya Tetap } & \multicolumn{2}{c}{\begin{tabular}{c} 
Petani Pengguna Benih \\
\multicolumn{2}{c}{ Bersertifikat }
\end{tabular}} & \multicolumn{2}{c}{ Petani Pengguna Benih } \\
& & \multicolumn{1}{c}{ Rp/UT } & \multicolumn{1}{c}{ Rp/Ha } & \multicolumn{1}{c}{ Rp/UT } & \multicolumn{1}{c}{ Rp/Ha } \\
\cline { 3 - 6 } & & $75.168,34$ & $168.911,11$ & $52.758,17$ & $83.342,74$ \\
\hline 1 & Penyusutan Alat & $3.977,78$ & $8.151,85$ & $5.409,09$ & $9.244,95$ \\
\hline 2 & Pajak Lahan & $79.146,12$ & $177.062,96$ & $58.167,26$ & $92.587,69$ \\
\hline
\end{tabular}

Sumber: Data Primer Diolah (2015)

\section{Biaya Variabel}

Penggunaan biaya pada usahatani padi sawah yang menggunakan benih bersertifikat lebih besar dibanding dengan biaya pada usahatani padi sawah yang menggunakan benih non sertifikat. Penggunaan biaya yang lebih besar tersebut disebabkan oleh jenis biaya yang dikeluarkan pada usahatani padi sawah yang menggunakan benih bersertifikat lebih besar dibanding dengan usahatani padi sawah yang menggunakan benih non sertifikat.

Tabel 3. Rata-Rata Penggunaan Biaya Variabel MT September-Desember 2014

\begin{tabular}{|c|c|c|c|c|c|}
\hline \multirow[t]{2}{*}{ No } & \multirow{2}{*}{$\begin{array}{c}\text { Jenis Biaya } \\
\text { Variabel }\end{array}$} & \multicolumn{2}{|c|}{$\begin{array}{c}\text { Petani Pengguna Benih } \\
\text { Bersertifikat }\end{array}$} & \multicolumn{2}{|c|}{$\begin{array}{c}\text { Petani Pengguna Benih } \\
\text { Non Sertifikat }\end{array}$} \\
\hline & & Rp/UT & $\mathrm{Rp} / \mathrm{Ha}$ & $\mathrm{Rp} / \mathrm{UT}$ & $\mathrm{Rp} / \mathrm{Ha}$ \\
\hline 1 & Biaya Benih & $216.000,00$ & $439.900,00$ & $84.852,27$ & $155.693,18$ \\
\hline \multirow[t]{3}{*}{2} & Biaya Pupuk & & & & \\
\hline & -Pupuk Padat & $673.333,33$ & $1.216 .666,67$ & $723.000,00$ & $1.140 .946,95$ \\
\hline & -Pupuk Cair & $8.666,67$ & $36.111,11$ & $5.909,09$ & $7.386,36$ \\
\hline \multirow[t]{3}{*}{3} & Biaya Pestisida & & & & \\
\hline & -Pestisida Padat & 0 & 0 & $34.545,45$ & $50.530,32$ \\
\hline & -Pestisida Cair & $60.366,67$ & $137.500,07$ & $84.113,64$ & $152.621,23$ \\
\hline \multirow[t]{4}{*}{4} & Upah TK & & & & \\
\hline & -TKDK & $317.283,33$ & 707.311,09 & $362.772,73$ & $623.286,63$ \\
\hline & -TKLK & $1.922 .666,67$ & 3.818.961,13 & 2.112.602,27 & $3.368 .996,27$ \\
\hline & Total & $3.198 .316,67$ & $6.356 .450,07$ & $3.407 .795,45$ & $5.499 .460,94$ \\
\hline
\end{tabular}

Sumber: Data Primer Diolah (2015)

\section{Penerimaan Usahatani}

Penerimaan usahatani dalam penelitian ini dihitung berdasarkan pendapatan nonriil dan riil. Penerimaan non riil merupakan penerimaan yang diperhitungkan yang berasal dari semua hasil dari usahatani padi yang dilakukan oleh petani baik untuk dijual langsung, dikonsumsi maupun hasil sampingan. Sementara penerimaan riil terdiri dari penerimaan yang hanya 
berasal dari penjualan produk atau padi yang dihasilkan oleh petani. Hasil estimasi penerimaan disajikan pada Tabel 4 dan 5.

Tabel 4. Rata-Rata Penerimaan nonriil Usahatani MT SeptemberDesember 2014

\begin{tabular}{|c|c|c|c|c|c|}
\hline \multirow[t]{2}{*}{ No } & \multirow{2}{*}{$\begin{array}{l}\text { Penerimaan } \\
\text { nonriil }\end{array}$} & \multicolumn{2}{|c|}{$\begin{array}{c}\text { Petani Pengguna Benih } \\
\text { Bersertifikat }\end{array}$} & \multicolumn{2}{|c|}{$\begin{array}{c}\text { Petani Pengguna Benih Non } \\
\text { Sertifikat }\end{array}$} \\
\hline & & Rp/UT & $\mathrm{Rp} / \mathrm{Ha}$ & Rp/UT & $\mathrm{Rp} / \mathrm{Ha}$ \\
\hline \multirow[t]{4}{*}{1} & Produk Dijual: & & & & \\
\hline & - GKP & $9.283 .333,33$ & $14.211 .666,67$ & $4.753 .272,73$ & $8.171 .545,45$ \\
\hline & - Beras & $2.737 .660,00$ & $7.717 .564,44$ & $6.044 .409,09$ & $7.508 .848,48$ \\
\hline & - Bekatul & $71.666,67$ & $229.444,44$ & $111.363,64$ & $156.060,61$ \\
\hline \multirow[t]{5}{*}{2} & Produk & & & & \\
\hline & Dikonsumsi: & & & & \\
\hline & - Beras & $456.733,33$ & $1.279 .466,67$ & $561.818,18$ & $290.909,09$ \\
\hline & - GKP & 0 & 0 & $218.181,82$ & $899.090,91$ \\
\hline & - Bekatul & 0 & 0 & $56.818,18$ & $57.575,76$ \\
\hline \multirow[t]{2}{*}{3} & Dijadikan Benih: & & & & \\
\hline & - GKP & $13.333,33$ & $26.666,67$ & $98.454,55$ & $116.909,09$ \\
\hline 4 & Bagi Hasil & $193.333,33$ & $483.333,33$ & $331.818,18$ & $809.090,91$ \\
\hline \multicolumn{2}{|c|}{ Total Penerimaan } & $12.756 .060,00$ & $23.948 .142,27$ & $12.176 .136,36$ & $18.010 .030,27$ \\
\hline
\end{tabular}

Sumber: Data Primer Diolah (2015)

Ket: Harga untuk produk yang dikonsumsi, dijadikan benih, dan bagi hasil diasumsikan sama dengan harga produk yang dijual

Tabel 5. Rata-Rata Penerimaan Riil Usahatani MT September-Desember 2014

\begin{tabular}{|c|c|c|c|c|c|}
\hline \multirow[t]{2}{*}{ No } & \multirow[t]{2}{*}{$\begin{array}{c}\text { Jenis } \\
\text { Penerimaan Real }\end{array}$} & \multicolumn{2}{|c|}{$\begin{array}{c}\text { Petani Pengguna Benih } \\
\text { Bersertifikat }\end{array}$} & \multicolumn{2}{|c|}{$\begin{array}{c}\text { Petani Pengguna Benih Non } \\
\text { Sertifikat }\end{array}$} \\
\hline & & Rp/UT & $\mathrm{Rp} / \mathrm{Ha}$ & Rp/UT & $\mathrm{Rp} / \mathrm{Ha}$ \\
\hline & Produk Dijual: & & & & \\
\hline 1 & GKP & $9.283 .333,33$ & $14.211 .666,67$ & $4.753 .272,73$ & $8.171 .545,45$ \\
\hline 2 & Beras & $2.737 .660,00$ & $7.717 .564,44$ & $6.044 .409,09$ & $7.508 .848,48$ \\
\hline 3 & Bekatul & $71.666,67$ & $229.444,44$ & $111.363,64$ & $156.060,61$ \\
\hline \multicolumn{2}{|c|}{ Total Penerimaan } & $12.092 .660,00$ & $22.158 .675,60$ & $10.909 .045,45$ & $15.836 .454,55$ \\
\hline
\end{tabular}

Tabel 4 dan 5 menunjukkan bahwa baik dengan konsep perhitungan unreal maupun dengan konsep perhitungan real, penerimaan terbesar tetap pada petani padi sawah pengguna benih bersertifikat. Hasil penerimaan yang besar tersebut disebabkan oleh produksi petani padi sawah pengguna benih bersertifikat yang lebih tinggi dibanding dengan petani pengguna benih non sertifikat. Dari kedua tabel juga menunjukkan bahwa pada petani pengguna benih bersertifikat, penerimaan unreal dan penerimaan real tidak jauh berbeda nilainya. Artinya pada petani pengguna benih bersertifikat produk yang diperuntukkan untuk dikonsumsi, dijadikan benih, dan juga untuk bagi hasil jumlahnya lebih sedikit dibanding dengan petani pengguna benih non sertifikat.

184 | Reza Raditya, Putri Suci Asriani, dan Sriyoto, Analisa Komparasi ... 


\section{Pendapatan Usahatani}

Estimasi pendapatan nonriil maupun riil usahatani padi diperoleh dengan mengurangkan penerimaan dengan biaya yang dikorbankan oleh petani, baik dalam penghirungan nonriil maupun riil. Hasil estimasi disajikan pada Tabel 6 .

\section{Tabel 6. Rata-Rata Pendapatan nonriil dan riil Usahatani Padi MT} September-Desember 2014

\begin{tabular}{|c|c|c|c|c|c|}
\hline \multirow[t]{2}{*}{ No } & \multirow[t]{2}{*}{ Uraian } & \multicolumn{2}{|c|}{$\begin{array}{c}\text { Petani Pengguna Benih } \\
\text { Bersertifikat }\end{array}$} & \multicolumn{2}{|c|}{$\begin{array}{c}\text { Petani Pengguna Benih Non } \\
\text { Sertifikat }\end{array}$} \\
\hline & & $\mathrm{Rp} / \mathrm{UT}$ & $\mathrm{Rp} / \mathrm{Ha}$ & $\mathrm{Rp} / \mathrm{UT}$ & $\mathrm{Rp} / \mathrm{Ha}$ \\
\hline \multicolumn{6}{|c|}{ Nonriil } \\
\hline 1 & Penerimaan & $12.756 .060,00$ & $23.948 .142,27$ & $12.176 .136,36$ & $18.010 .030,27$ \\
\hline 2 & Biaya & $3.277 .462,79$ & $6.533 .513,03$ & $3.465 .962,71$ & $5.592 .048,63$ \\
\hline 3 & Pendapatan & $9.478 .597,21$ & $17.414 .629,24$ & $8.710 .173,65$ & $12.417 .981,64$ \\
\hline \multicolumn{6}{|c|}{ Uji beda } \\
\hline & $t_{\text {hitung }}$ & \multicolumn{4}{|c|}{4,83} \\
\hline & $t_{\text {tabel }}$ & \multicolumn{4}{|c|}{1,69} \\
\hline \multicolumn{6}{|c|}{ Riil } \\
\hline 1 & Penerimaaan & $12.092 .660,00$ & $22.158 .675,60$ & $10.909 .045,45$ & $15.836 .454,55$ \\
\hline 2 & Biaya & 2.885.011,12 & $5.657 .290,83$ & $3.050 .431,81$ & $4.885 .419,26$ \\
\hline 3 & Pendapatan & $9.207 .648,88$ & $16.501 .384,77$ & $7.858 .613,64$ & $10.951 .035,29$ \\
\hline \multicolumn{6}{|c|}{ Uji beda } \\
\hline & $t_{\text {hitung }}$ & \multicolumn{4}{|c|}{4,17} \\
\hline & $t_{\text {tabel }}$ & \multicolumn{4}{|c|}{1,69} \\
\hline
\end{tabular}

Sumber: Data Primer Diolah (2015)

Tabel 6 menunjukkan bahwa baik dengan konsep perhitungan unreal maupun dengan konsep perhitungan real, pendapatan terbesar tetap pada petani padi sawah pengguna benih bersertifikat. Hasil pendapatan yang besar tersebut disebabkan oleh penerimaan petani padi sawah pengguna benih bersertifikat yang lebih tinggi dibanding dengan petani pengguna benih non sertifikat. Walaupun biaya usahatani yang dikeluarkan oleh petani pengguna benih bersertifikat lebih besar dibanding dengan biaya usahatani yang dikeluarkan oleh petani pengguna benih non sertifikat, akan tetapi petani pengguna benih bersertifikat tetap dapat memperoleh pendapatan yang lebih besar karena disebabkan oleh penerimaan yang tinggi dari hasil usahatani dengan menggunakan benih bersertifikat. Dari kedua tabel juga menunjukkan bahwa pada petani pengguna benih bersertifikat, pendapatan unreal dan pendapatan real tidak jauh berbeda nilainya. Artinya pada petani pengguna benih bersertifikat masih memperoleh keuntungan yang hampir sama apabila biaya yang tidak diperhitungkan tetap dibayarkan.

Hipotesis yang diajukan dalam penelitian ini adalah pendapatan pada usahatani padi sawah yang menggunakan benih bersertifikat lebih tinggi daripada pendapatan pada usahatani padi sawah yang menggunakan benih non sertifikat. Uji perbandingan ( $t$-test) terhadap pendapatan nonriil dan riil antara 
pada usahatani padi sawah pengguna benih bersertifikat dan benih non sertifikat memberikan nilai t-hitung lebih besar daripada nilai $t$-tabel. Hasil ini menunjukkan bahwa pendapatan pada usahatani padi sawah yang menggunakan benih bersertifikat lebih tinggi daripada pendapatan pada usahatani padi sawah yang menggunakan benih non sertifikat, baik pada estimasi riil maupun non riil.

\section{Analisis Efisiensi Usahatani}

Tabel 7. Rata-Rata Efisiensi Usahatani Padi Sawah MT SeptemberDesember 2014

\begin{tabular}{|c|c|c|c|}
\hline No & Uraian & $\begin{array}{c}\text { Petani Pengguna Benih } \\
\text { Bersertifikat }\end{array}$ & $\begin{array}{c}\text { Petani Pengguna Benih } \\
\text { Non Sertifikat }\end{array}$ \\
\hline \multicolumn{4}{|c|}{ Nonriil } \\
\hline 1 & Penerimaan (Rp/Ha) & $23.948 .142,27$ & $18.010 .030,27$ \\
\hline 2 & Biaya $(\mathrm{Rp} / \mathrm{Ha})$ & $6.533 .513,03$ & $5.592 .048,63$ \\
\hline 3 & $R / C$ ratio & 3,66 & 3,22 \\
\hline \multicolumn{4}{|c|}{ Riil } \\
\hline 1 & Penerimaan (Rp/Ha) & $22.158 .675,60$ & $15.836 .454,55$ \\
\hline 2 & Biaya (Rp/Ha) & $5.657 .290,83$ & $4.885 .419,26$ \\
\hline 3 & $R / C$ ratio & 3,91 & 3,24 \\
\hline
\end{tabular}

Sumber: Data Primer Diolah (2015)

Hasil analisis menunjukkan nilai $R / C$ Ratio nonriil pada usahatani padi sawah oleh petani padi sawah pengguna benih bersertifikat dan benih non sertifikat masing-masing sebesar 3,66 dan 3,22. Nilai R/C Ratio tersebut menunjukkan bahwa usahatani padi sawah oleh petani padi sawah pengguna benih bersertifikat dan benih non sertifikat efisien karena nilai $R / C$ Ratio dari kedua usahatani tersebut lebih dari satu. Sementara pada estimasi nilai riil, hasil analisis menunjukkan nilai $R / C$ Ratio pada usahatani padi sawah oleh petani padi sawah pengguna benih bersertifikat dan benih non sertifikat masingmasing sebesar 3,91 dan 3,24. Nilai R/C Ratio tersebut menunjukkan bahwa usahatani padi sawah oleh petani padi sawah pengguna benih bersertifikat dan benih non sertifikat juga efisien.

\section{SIMPULAN DAN SARAN}

\section{Simpulan}

Berdasarkan hasil penelitian tentang analisis komparasi usahatani padi sawah pengguna benih bersertifikat dan benih non sertifikat di Kelurahan Kemumu Kecamatan Arma Jaya Kabupaten Bengkulu Utara, dapat diambil kesimpulan antara lain: 
1. Produktivitas lahan pada usahatani oleh petani padi sawah pengguna benih bersertifikat (5,112 Ton/Ha) terbukti lebih tinggi daripada produktivitas lahan pada usahatani oleh petani padi sawah pengguna benih non sertifikat $(3,918 \mathrm{Ton} / \mathrm{Ha})$.

2. Uji perbandingan terhadap produktivitas lahan menyatakan bahwa produktivitas lahan pada usahatani padi sawah yang menggunakan benih bersertifikat lebih tinggi daripada produktivitas lahan pada usahatani padi sawah yang menggunakan benih non sertifikat, karena nilai t-hitung $(5,06)>$ nilai t-tabel $(1,69)$.

3. Pendapatan pada usahatani oleh petani padi sawah pengguna benih bersertifikat ( $\mathrm{Rp}$ 16.501.384,77/Ha) terbukti lebih tinggi daripada pendapatan pada usahatani oleh petani padi sawah pengguna benih non sertifikat (Rp 10.951.035,29/Ha).

4. Uji perbandingan terhadap pendapatan menyatakan bahwa pendapatan pada usahatani padi sawah yang menggunakan benih bersertifikat lebih tinggi daripada pendapatan pada usahatani padi sawah yang menggunakan benih non sertifikat, karena nilai t-hitung $(4,17)>$ nilai t-tabel $(1,69)$.

5. Usahatani padi sawah oleh petani padi sawah pengguna benih bersertifikat $(\mathrm{R} / \mathrm{C}$ ratio $=3,91)$ lebih efisien daripada usahatani padi sawah oleh petani padi sawah pengguna benih non sertifikat $(\mathrm{R} / \mathrm{C}$ ratio $=3,24)$.

\section{Saran}

Berdasarkan hasil penelitian tentang analisis komparasi usahatani padi sawah pengguna benih bersertifikat dan benih non sertifikat di Keluraha Kemumu Kecamatan Arma Jaya Kabupaten Bengkulu Utara, maka saran yang akan diberikan antara lain sebagai berikut:

1. Dari segi produktivitas, pendapatan, dan efisiensi benih bersertifikat lebih baik dibanding dengan benih non sertifikat. Oleh karena itu PT PERTANI UPB Sukasari selaku produsen dan penyedia benih bersertifikat harus tetap menjaga kualitas dari benih bersertifikat agar petani tetap ingin melakukan usahatani menggunakan benih bersertifikat. Sementara itu, kualitas dari benih non sertifikat juga harus ditingkatkan lagi agar petani memiliki pilihan yang lebih baik dalam memilih benih non sertifikat apabila terjadi keterbatasan stok dari benih bersertifikat.

2. Dari hasil analisis terhadap produktivitas lahan, pendapatan, dan efisiensi menunjukkan bahwa benih bersertifikat lebih baik daripada benih non sertifkat. Oleh karena itu sebaiknya petani melakukan usahatani padi sawah menggunakan benih bersertifikat agar petani bisa mendapatkan keuntungan dari usahatani yang mereka lakukan, terutama keuntungan dari segi pendapatan. Selain itu dari sisi peningkatan kualitas, perlu adanya juga bantuan dari pihak yang terkait dengan peningkatan kualitas benih agar bisa memberikan bantuan kepada para penangkar benih agar benih non sertifikat 
juga bisa memiliki kualitas yang baik, sehingga petani yang menggunakan benih non sertifikat juga bisa mendapatkan keuntungan dari segi produktivitas lahan, pendapatan, dan juga efisiensi.

\section{DAFTAR PUSTAKA}

Badan Pusat Statistik. 2009. Produktivitas Padi Provinsi Bengkulu. BPS Provinsi Bengkulu. Bengkulu.

. 2013. Kabupaten Bengkulu Utara Dalam Angka. BPS Provinsi Bengkulu. Bengkulu.

Mubyarto. 1991. Pengantar Ekonomi Pertanian. LP3ES. Jakarta.

Nazir. 1983. Metode Penelitian. Ghalia Indonesia. Jakarta.

Soekartawi. 1995. Analisis Usaha Tani. UI Press. Jakarta.

. 2002. Prinsip Dasar Ekonomi Pertanian Teori dan Aplikasinya. Raja Grafindo Persada. Jakarta. 